\section{Water-based Cold Protection of Chill-sensitive Foliage Plants in Shadehouses}

\author{
Robert H. Stamps ${ }^{1}$ \\ University of Florida, Mid-Florida Research and Education Center, Institute \\ of Food and Agricultural Sciences, Apopka, FL 32703
}

Seenivasan Natarajan

Andhra Pradesh Horticultural University, Venkatramannagudem, Tadepalligudem 534101, Andhra Pradesh, India

Lawrence R. Parsons

University of Florida, Citrus Research and Education Center, Institute of Food and Agricultural Sciences, Lake Alfred, FL 33850

\section{Jianjun Chen \\ University of Florida, Mid-Florida Research and Education Center, Institute of Food and Agricultural Sciences, Apopka, FL 32703}

Additional index words. chilling injury, fog, frost, mist, cold damage

\begin{abstract}
Four water-based cold protection systems [under-benches mist (UBM), overroadways mist (ORM), and two among-plants fog (APF1, APF2)] were evaluated for their water use and effectiveness in protecting ornamental foliage plants from chilling injury (CI) under protected shade structures at three commercial locations in Florida. UBM used a two-stage thermostat-controlled system with mist nozzles on $25-\mathrm{cm}$ above-ground risers combined with an overhead retractable heat curtain. Both ORM and APF1 had seasonally applied polyethylene film cladding and manually controlled irrigation systems. The ORM system had the mist nozzles located $1.8 \mathrm{~m}$ high and APF1 and APF2 systems had the lowpressure fog nozzles mounted on $25-\mathrm{cm}$ above-ground risers spaced among the plants. Temperature data loggers were placed outside and inside the northwest sections of the shadehouses. ORM and the two APF systems were evaluated during freeze events in 2006, 2007, and 2008 and UBM only in 2007 and 2008. UBM, ORM, and APF1 successfully kept the shadehouse temperatures above critical chilling temperatures for all of the foliage plants. APF2 protected all foliage crops except for jungle drum "palm" (Carludovica sp.) that sustained CI. At the UBM site, the air temperatures recorded inside the shadehouse were $\approx 17^{\circ} \mathrm{C}$ warmer than outside. Both ORM and APF1 maintained adequately warm temperatures inside the shadehouses; however, the fog system maintained equal or higher temperatures than the mist system and used $86 \%$ less water. Inside temperatures were lower with APF2 than APF1 although the emitter type was the same and the water application rates were similar. These temperature differences were attributable to the greater APF2 shadehouse surface area (SA) and volume (V) compared with APF1 and indicate that the $\mathrm{SA}$ and $\mathrm{V}$ of structures being heated need to be considered when designing water-based low-pressure fog heating systems. The ORM and both fog systems conserved water compared with using the conventional sprinkler irrigation systems. These results show the potential of water-based approaches for maintaining shadehouses above chilling temperatures during freeze events.
\end{abstract}

\footnotetext{
Received for publication 10 Feb. 2010. Accepted for publication 30 Aug. 2010.

We thank the Southwest Florida Water Management District and the Florida Agricultural Experiment Station for financial support, James Holeton and Jesse Anderson for technical support, and the cooperating nurseries.

Mention of a trademark, proprietary product, or vendor does not constitute a guarantee or warranty of the product by the University of Florida and does not imply its approval to the exclusion of other products or vendors that also may be suitable.

${ }^{1}$ To whom reprint requests should be addressed; e-mail rstamps@ufl.edu.
}

Foliage plants are extensively used in interior and outdoor landscaping as a result of their diverse forms, attractive colors, and textures. The value of foliage plant production in the United States was \$401 million at wholesale in 2009 (USDA/NASS, 2010). Florida continues to dominate this market and accounts for $67 \%$ of total production. Florida's climate is well suited for growing a large variety of subtropical and tropical foliage plants. However, potentially damaging cold events occur every year in Florida (National Climate Data Center, 2008). In fact, the freezes in the 1980 s forced the Citrus Industry to relocate to warmer southern areas of the state (Yelenosky, 1997). Water-based cold protection of crops has been extensively used in Florida since the1960s (Harrison et al., 1974). Studies in Florida citrus groves have reported the benefits of using water for cold protection (Parsons et al., 1982, 1985, 1991a, 1991b). Research on the beneficial effects of using water for cold protection of other crops grown outdoors such as apples and strawberries has also been conducted (Heinemann et al., 1992; Koc et al., 2000; Stombaugh et al., 1992).

Unlike those crops, most tropical and subtropical foliage plants in Florida are grown in containers and produced in protective structures - greenhouses and shadehouses. In addition, these chill-sensitive plants can be injured at temperatures several degrees above freezing. Foliage growers use various heating methods to protect the plants during cold events. Conventional methods of heating such as electric heaters and solid/liquid/gas fuel burners are expensive to install and costly to run and maintain and, therefore, significantly increase the cost of plant production. Burning fuels can cause crop and environmental damage from air pollution. Because of these issues, some growers have used water as a less expensive and cleaner source to heat inside the structures. However, water management districts are reluctant to have water, especially groundwater, used for this purpose. In fact, in one of the approved water conservation plans for ferneries/nurseries, Florida's St. Johns River Water Management District has mandated a maximum water application rate using over-the-crop sprinkler systems for cold protection of $935 \mathrm{~L} \cdot \mathrm{min}^{-1} \cdot \mathrm{ha}^{-1}$ (St. Johns River Water Management District, 2004). However, a minimum water application rate of 1300 to $1478 \mathrm{~L} \cdot \mathrm{min}^{-1} \cdot \mathrm{ha}^{-1}$ has been recommended for cold protection of subtropical leatherleaf fern in Florida (Stamps and Haman, 1991). Only a few studies have reported on the use of waterbased cold protection for foliage plant production in shadehouses and in all of these, the crop was leatherleaf fern [Rumorha adiantiformis (Forst.) Ching], which is grown in the ground (Stamps, 1989, 1991, 1994; Stamps and Haman, 1991; Stamps and Mathur, 1982; Stamps and McColley, 1996). In these studies, techniques to reduce the amount of water use using different sprinkler systems for cold protection have been reported. However, none of these studies dealt with potted foliage plants produced in shadehouses that had been lined during cold weather using heat-retention curtains and/or polyethylene sheeting.

In this study, four water-based cold protection systems were evaluated across a 3-year period. The objective was to determine the effectiveness of the four systems in cold protection and in water conservation during the production of potted foliage plants in heatretention curtain and/or polyethylene-clad shadehouses.

\section{Materials and Methods}

After conducting a survey of numerous nursery operations in Florida, four water-based cold protection systems (UBM, ORM, APF1, APF2; Table 1) located at three commercial 
Table 1. Cold protection system designation, emitter locations, types, models, orifice sizes, operating pressures and number of emitters/ha, and resultant water application rates evaluated for the four water-based cold protection systems.

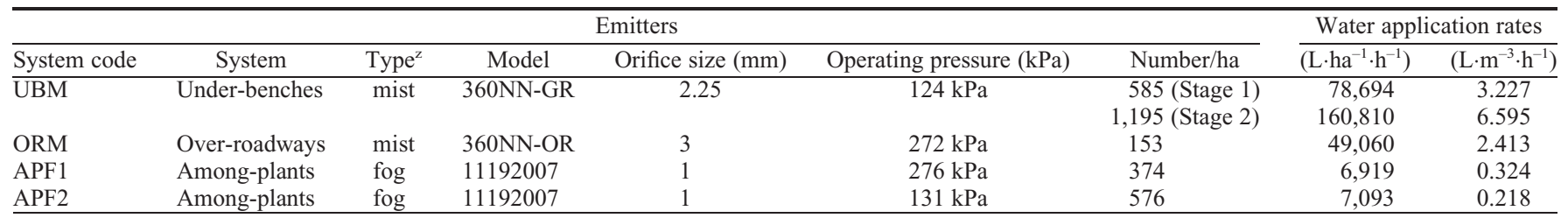

${ }^{2}$ Mist and fog nozzles were made, respectively, by Dramm Mfg., Manitowoc, WI, and NaanDan Jain Irrigation, Post Naan, Israel.

$\mathrm{UBM}=$ under-bench mist; ORM = over-the-roadways; APF = among-plants fog.

nurseries were selected for this study. Waterbased cold protection systems at these locations (Fig. 1) used mist and fog emitters rather than conventional overhead irrigation systems. Water application rates for cold protection based on shadehouse areas and volumes ranged from 6,919 to $160,810 \mathrm{~L} \cdot \mathrm{ha}^{-1} \cdot \mathrm{h}^{-1}$ and from 0.22 to $6.6 \mathrm{~L} \cdot \mathrm{m}^{-3} \cdot \mathrm{h}^{-1}$, respectively. The water used at all sites came from the Floridan aquifer for which the temperature is relatively constant for a given below-ground depth, averaging $\approx 22$ to $26{ }^{\circ} \mathrm{C}$ at the depths normally used for nursery irrigation wells. UBM was evaluated during 2007 and 2008 cold events and the three others were evaluated during 2006, 2007, and 2008.

Under-benches mist details. This shadehouse, located in Apopka, FL, was $88 \mathrm{~m} \times 67$ $\mathrm{m} \times 2.4 \mathrm{~m}$ tall and used to produce various types of bromeliads. The structure was covered with woven polypropylene shade fabric designed to provide $73 \%$ shade. For cold protection, this shadehouse had an interior, overhead, white woven polyethylene, retractable heat-retention curtain (RHC; Cravo Equipment, Brantford, Ontario, Canada) across the ceiling, polyethylene sheeting covering the sidewalls, and an under-the-benches mist system that was turned on in two stages using a dual-stage thermostat. The mist nozzles were located $25 \mathrm{~cm}$ above ground on risers spaced $1.8 \mathrm{~m} \times 3.6 \mathrm{~m}$ apart. The thermostat was set at $15{ }^{\circ} \mathrm{C}$ to turn on the mist system if the temperature dropped below this set point. Initially (Stage 1) half the misters were turned on and then, if necessary, Stage 2 was activated and all the misters were turned on. In this study, thermistors of data loggers were placed at five places in the shadehouse - above the RHC, just below the RHC, plant height (center and perimeter), in the potting medium, and under the benches (Fig. 1, UBM).

Over-roadways mist details. Both this system (ORM) and the next one (APF1) were located at a nursery in Zolfo Springs, FL, and were turned on when the temperatures inside the shadehouses dropped to $7^{\circ} \mathrm{C}$. They were turned off when temperatures rose back to that same set point. To monitor temperature changes, thermistors were mounted at plant height $0.6 \mathrm{~m}$ above the ground and at the same height outside for both systems. The 84 $\mathrm{m} \times 121 \mathrm{~m} \times 2.0-\mathrm{m}$ shadehouse was filled with agloenemas, anthuriums, calatheas, and spathiphyllums. The shadehouse was covered year-round with $80 \%$ polypropylene shade fabric and seasonally lined with polyethylene film. The mist heating system, consisting of

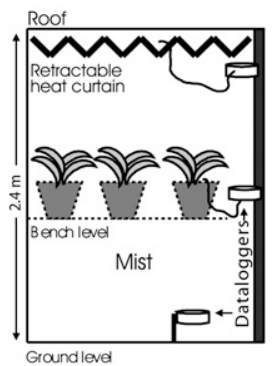

UBM

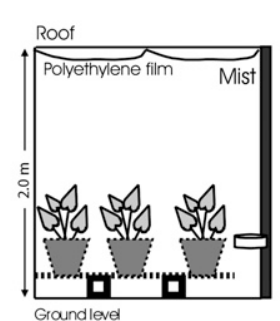

ORM

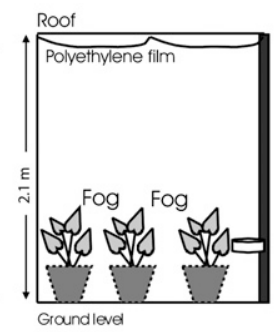

APF1

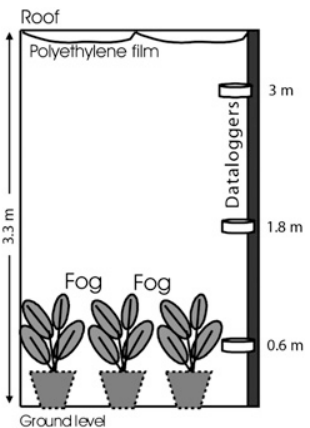

APF2
Fig. 1. Illustration of cross sectional view of four shadehouse cold protections systems. UBM is an underbench mist system in a 2.4-m-tall shadehouse with retractable heat curtain. ORM is an over-roadway mist system in a 2.0-m-tall polyethylene-clad shadehouse. APF1 is an among-plants fog system in a 2.1-m-tall polyethylene-clad shadehouse. APF2 is an among-plants fog system in a 3.3-m-tall polyethylene-clad shadehouse. Locations for data loggers used to record temperatures from thermistors are represented in the figures.

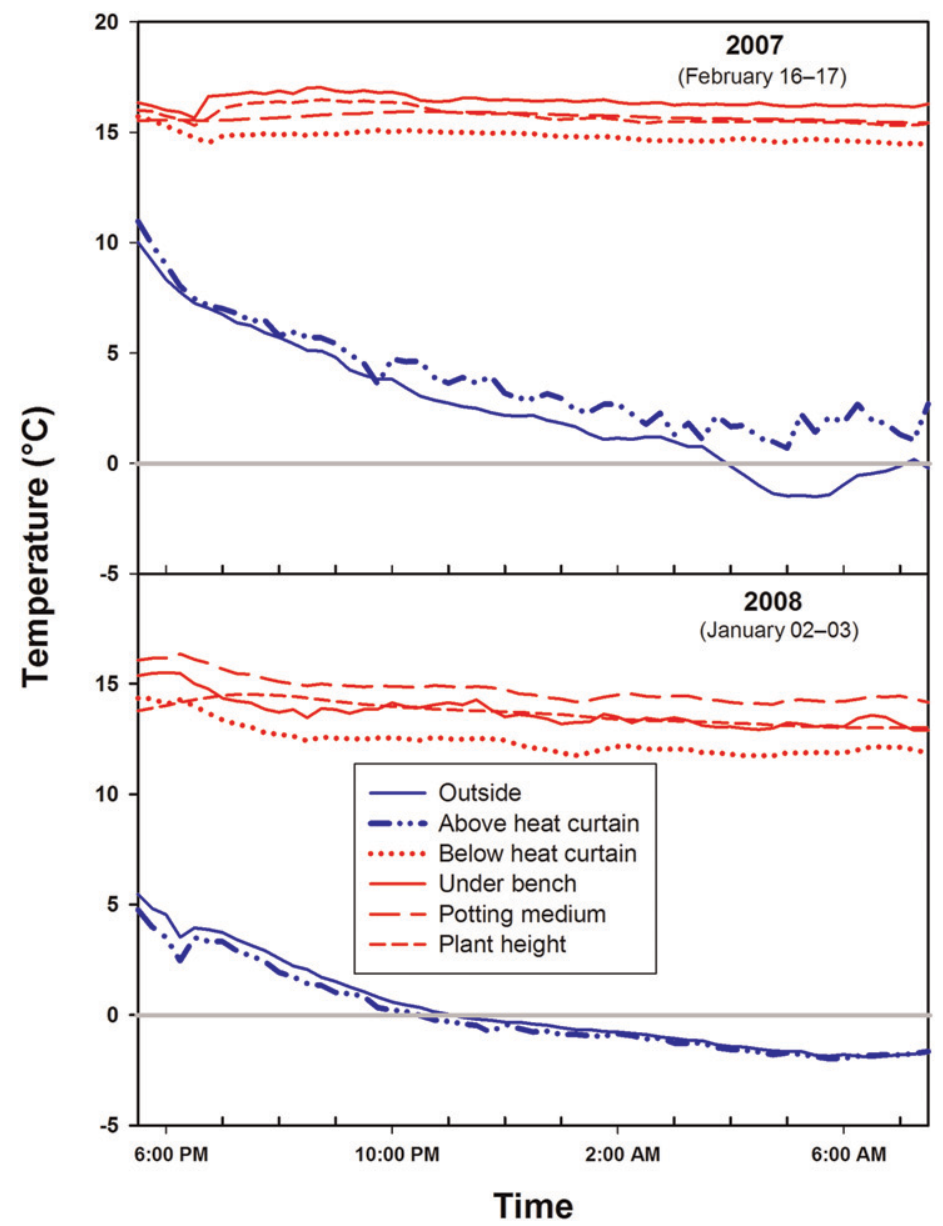

Fig. 2. Dusk to dawn temperature profiles outside and inside an under-the-benches mist (UBM)-heated shadehouse during the coldest nights in 2007 and 2008. 
over-the-roadways nozzles spaced on 3.7-m centers, was manually controlled.

Among-plants fog 1 details. This shadehouse was $69 \mathrm{~m} \times 117 \mathrm{~m} \times 2.1 \mathrm{~m}$, clad in polyethylene film, and heated using low-pressure fog nozzles mounted on $25-\mathrm{cm}$ above-ground risers distributed among the plants and spaced $3.6 \mathrm{~m} \times 7.3 \mathrm{~m}$ apart. The shadehouse was covered year-round with woven polypropylene shade fabric designed to provide $73 \%$ shade. This shadehouse was used to produce agloenemas, anthuriums, ctenanthes, and spathiphyllums. For the winter, the shadehouse was lined with the same polyethylene film used in the ORM-heated shadehouse.

Among-plants fog 2 details. This $206 \mathrm{~m} \times$ $139 \mathrm{~m} \times 3.3-\mathrm{m}$ shadehouse was located in Wauchula, FL, and was filled with chamaedoreas, ctenanthes, dracaenas, jungle drum "palm" (Carludovica 'Jungle Drum'), nephrolepis, and spathiphyllums. The shadehouse structure was covered with woven polypropylene shade fabric designed to provide $73 \%$ shade. For cold protection, seasonally applied polyethylene film cladding was used along with a low-pressure among-the-plants fog system. Fog nozzles were mounted on $27-\mathrm{cm}$ risers spaced $2.7 \mathrm{~m} \times 5.5 \mathrm{~m}$ apart. The fog system was turned on when the temperature inside the shadehouse dropped to $8{ }^{\circ} \mathrm{C}$ and was stopped when it rose back to that same temperature. Because this was the tallest shadehouse in this study, data loggers in this study were placed at three different heights $0.6,1.8$, and $3 \mathrm{~m}$ above the ground, both inside and outside the shadehouse to monitor possible vertical temperature differences.

Data loggers with attached thermistors (HOBO H08 Pro; Onset Computer Corp. Pocasset, MA) were fitted with irrigation/rain shields and mounted both inside and outside the northwest sides of shadehouses and were set to record the temperatures in high resolution mode at 15 -min intervals. Outside temperatures were replicated twice and interior temperatures twice (UBM) or three times (ORM, APF1, APF2) each year for each location and elevation. Temperatures recorded for specific locations were averaged and graphed for the coldest night of each year (Sigma Plot; Systat Software, Chicago, IL). Wind speed data were collected from two Florida Automated Weather Network weather stations (http://fawn.ifas.ufl.edu) closest to the study sites. Wind speed readings were made every 15 min at a height of $10 \mathrm{~m}$ using an ultrasonic anemometer (WS425-SDI-12; Vaisala, Helsinki, Finland). Water pressure and temperature readings were taken at six randomly selected emitter heads in each shadehouse using calibrated pressure gauges (7LF-60; Irrometer, Riverside, CA) attached to pitot tubes and mercury thermometers. Water flow rate curves for the emitters were created using a manifold equipped with pressure regulators, calibrated pressure gauges, and tubing to collect the water emitted during fixed time intervals. System operating pressures and emitter flow rates and densities were used to calculate water application rates for each system.
Where applicable, analysis of variance tests were conducted using the PROC GLM procedure of the Statistical Analysis System (SAS ${ }^{\circledR}$ Institute, Version 9, Cary, NC) and mean differences were determined using Duncan's multiple range test at $P \leq$ 0.05 .

Chilling can cause notable injury to foliage plant leaves; the symptoms include chlorosis, necrosis, water-soaked patches, or wilting (Chen et al., 2001). To determine if CI occurred to the foliage plants, visual examina- tion of foliage plant leaves was conducted after each cold event.

\section{Results and Discussion}

Under-bench mist. Temperatures outside and inside the shadehouse depict the cold protection provided by protected structures and water application (Fig. 2). During the cold events on 16 to $17 \mathrm{Feb} .2007$ and 2 to 3 Jan. 2008 , the temperatures outside the shadehouse remained below $0{ }^{\circ} \mathrm{C}$ for $4.5 \mathrm{~h}$ in 2007 and $9 \mathrm{~h}$

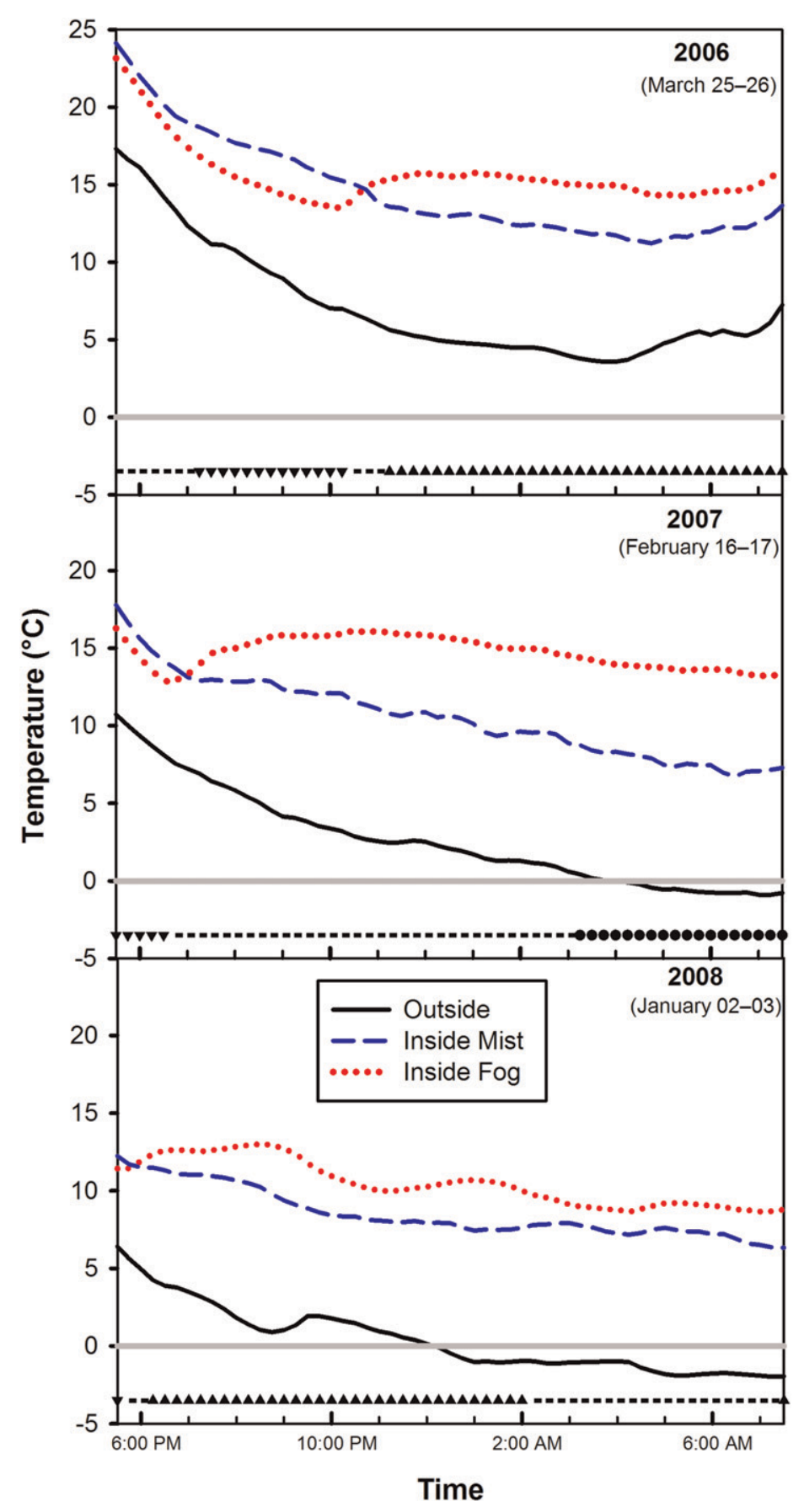

Fig. 3. Dusk to dawn temperature profiles outside $(\mathrm{O})$ and inside an over-the-roadways mist (ORM)- and an among-the-plants fog (APF1)-heated shadehouse during the coldest nights in 2006, 2007, and 2008. Symbols at the bottom of the graph for each year indicate whether there were significant temperature differences at each time (Duncan's new multiple range test at $P=0.05$ ): $\boldsymbol{\nabla}=\mathrm{ORM}>\mathrm{APF} 1 ;-=\mathrm{ORM}=$ APF1; $\boldsymbol{\Delta}=\mathrm{ORM}<\mathrm{APF} 1$ (both ORM and APF1 $>\mathrm{O}$ ); and $\bullet=\mathrm{APF} 1>\mathrm{O}, \mathrm{ORM}=\mathrm{APF} 1$ but ORM $=\mathrm{O}$. 
in 2008 and reached lows of $-1.5{ }^{\circ} \mathrm{C}$ and $-1.9^{\circ} \mathrm{C}$ in 2007 and 2008 , respectively. In 2007, the temperature inside the shadehouse at plant foliage height never dropped below the $15^{\circ} \mathrm{C}$ set point. Plant height air temperatures dropped as low as $12.4{ }^{\circ} \mathrm{C}$ in 2008 ; however, no plant damage was observed. The differences between the 2 years are likely the result of differences in wind conditions. Average, maximum, and minimum wind conditions were all higher in 2008 than 2007-5.23 versus $3.4,11.5$ versus 10 , and 1.5 versus $0 \mathrm{~m} \cdot \mathrm{s}^{-1}$, respectively. The temperature differential above and below the heat-retention curtain was $\approx 13{ }^{\circ} \mathrm{C}$ at its maximum both years, indicating the curtain's effectiveness. Heating inside the shadehouse was fairly uniform with the temperature differences from under the benches where the water was applied to just below the heat-retention curtain never greater than $1.9^{\circ} \mathrm{C}$. The mist system operated at Stage 2 for almost the entire time the system was on during these two freeze events.

Over-roadway mist and among-plant fog 1 . Temperatures outside and inside the ORMand APF1-heated shadehouses showed fairly consistent results across the 3 years with each year getting progressively colder (Fig. 3). During the cold event on 25 to 26 Mar. 2006, the temperatures outside the shadehouse remained below $5{ }^{\circ} \mathrm{C}$ for $5 \mathrm{~h}$ and reached as low as $3.6{ }^{\circ} \mathrm{C}$. However, during the cold events on 16 to $17 \mathrm{Feb} .2007$ and 2 to 3 Jan. 2008, the temperatures outside the shadehouses remained below $0{ }^{\circ} \mathrm{C}$ for $4 \mathrm{~h}$ and $8.5 \mathrm{~h}$, respectively, and reached lows of -0.9 and $-2{ }^{\circ} \mathrm{C}$, respectively. Although the temperatures inside the shadehouses were maintained at or near the critical temperature $\left(7^{\circ} \mathrm{C}\right)$ and no crop damage was observed, there were significant temperature differences between the two systems.

In 2006, the grower turned the ORM system on before the APF1, but once the fog system was started, it consistently maintained warmer temperatures throughout the rest of the night. The APF1 system maintained temperatures $\approx 3{ }^{\circ} \mathrm{C}$ warmer using $86 \%$ less water than the ORM system (Table 1). Temperatures were lower on the coldest night in 2007 and both systems performed similarly despite the large difference in water application rates. In 2008, the fog system initially maintained warmer temperatures, but after $0200 \mathrm{HR}$, the heating limitations imposed by the relatively low water application rate overcame the greater efficiency in releasing heat and the two systems maintained similar temperatures on this, the coldest and windiest of the 3 years. No visible damage symptoms were observed on the crops in either shadehouse.

Among-plants fog 2. This shadehouse was the tallest one evaluated in this study and had an among-the-plants fog system similar to APF1. During the cold events on 25 to 26 Mar. 2006, the temperatures outside the shadehouse remained at or below $5{ }^{\circ} \mathrm{C}$ for $7.25 \mathrm{~h}$ and reached as low as $3{ }^{\circ} \mathrm{C}$. During the cold events on 16 to 17 Feb. 2007 and 2 to 3 Jan. 2008, the temperatures outside the shadehouse remained at or below $0{ }^{\circ} \mathrm{C}$ for $2.5 \mathrm{~h}$ in 2007 and $7.5 \mathrm{~h}$ in 2008 and reached as low as $-0.4{ }^{\circ} \mathrm{C}$ and

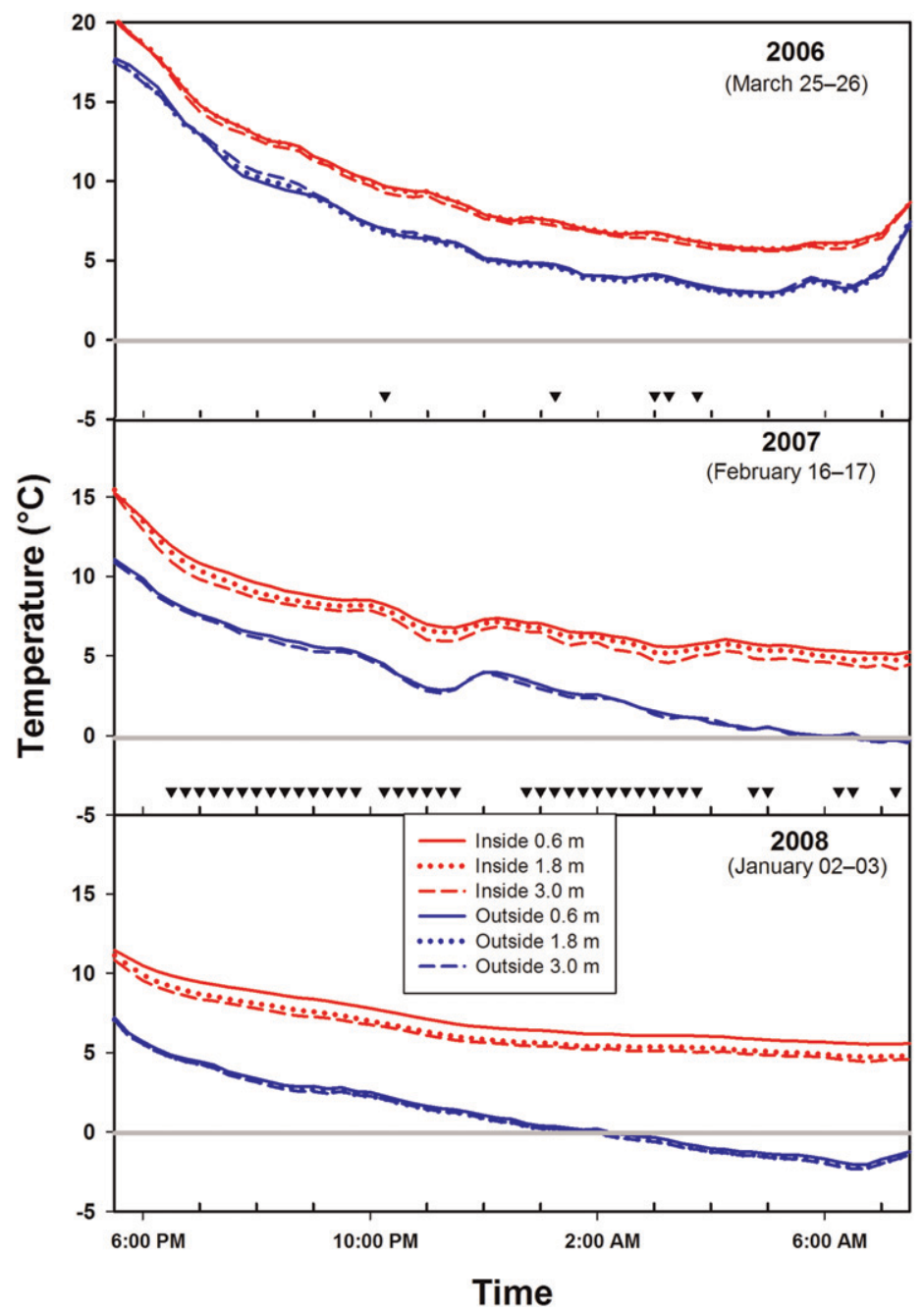

Fig. 4. Dusk to dawn temperature profiles outside and inside a second among-the-plants fog system (APF2)-heated shadehouse during the coldest nights in 2006, 2007, and 2008. Symbols at the bottom of the graph for each year indicate that there were significant temperature differences resulting from elevation among the inside temperatures at that time (Duncan's new multiple range test at $P=0.05$ ): $\boldsymbol{\nabla}=$ inside temperatures at $3 \mathrm{~m}<$ at $0.6 \mathrm{~m}$ (inside temperatures at 0.6 and $1.8 \mathrm{~m}$ were never different from each other and there were no differences between the outside temperatures as a result of height).

$-2.2{ }^{\circ} \mathrm{C}$ in 2007 and 2008, respectively (Fig. 4). During all 3 years, the system consistently failed to maintain the inside set point temperature of $8{ }^{\circ} \mathrm{C}$. During these three cold events, duration of inside temperatures below the set point temperature was $10 \mathrm{~h}$ in $2006,14.75 \mathrm{~h}$ in 2007 , and $17.25 \mathrm{~h}$ in 2008 . In addition, the 24$\mathrm{h}$ average wind speeds increased each year from 2.1 to 2.5 to $2.9 \mathrm{~m} \cdot \mathrm{s}^{-1}$. Despite this, none of the foliage plants sustained CI except jungle drum "palm" (Carludovica sp.). Therefore, under these conditions and with all these crops except one, $8^{\circ} \mathrm{C}$ was not a critical threshold for chill damage. This is consistent with research that has shown that a number of cultivars of Dieffenbachia, considered a chill-sensitive foliage plant, can tolerate exposure to temperatures as low as $2{ }^{\circ} \mathrm{C}$ for $12 \mathrm{~h}$ without sustaining CI (Li et al., 2008).

Temperature data at different heights inside the shadehouse did not differ much at this location in 2006. This lack of differences could be the result of the relatively mild temperatures during the cold event in 2006. During the colder event in 2007, tempera- tures at the 3-m height were often lower (by 1 to $1.9^{\circ} \mathrm{C}$ ) than at the $0.6-\mathrm{m}$ height where the fog emitters were located. There were no differences resulting from height in 2008 . The winds were stronger and temperatures inside the shadehouse at any given height were more variable than in 2007.

Based on experience in the industry and survey instrument responses before this study, the majority of the foliage plant growers in Florida use conventional heating systems for cold protection; however, mist systems are somewhat common. Fog systems are being used at only a few locations. It has been estimated that cold protecting using fog may require only $20 \%$ and $0.3 \%$ of the fuel energy compared with using sprinkler irrigation or combustion heaters, respectively (Mee and Bartholic, 1979). This is the first study to report the performance of mist or fog systems for cold protection of potted foliage plants in shadehouses and to evaluate their water use efficiencies during the cold events. For UBM in which the critical temperature set point was $15^{\circ} \mathrm{C}$, an under-the-bench mist system in 
combination with heat curtains was successful. However, water application rates were actually higher than if the regular over-the-crop irrigation system had been used (data not shown). The cold protection water application rates for the other sites were 54\% (mist) and 90\% (fog) less than the respective crop irrigations systems (data not shown) at those sites. Results comparing ORM and APF1 suggest that fog systems have the potential to save water compared with mist systems. Comparisons of the two fog systems, APF1 and APF2, illustrate the need to consider the heated volume of the structures rather than just the footprint of the shadehouses when designing cold protection systems.

These results show the water savings potential of low-pressure fog-based systems for heating shadehouses. Further research is needed to maximize the heating capabilities of fog-based systems and to better define the water application rates required to maintain specific set points in shadehouses of various volumes.

\section{Literature Cited}

Chen, J., R.W. Henley, R.J. Henny, R.D. Caldwell, and C.A. Robinson. 2001. Aglaonema cultivars differ in resistance to chilling temperatures. J. Environ. Hort. 19:198-202.

Harrison, D.S., J.F. Gerber, and R.E. Choate. 1974. Sprinkler irrigation for cold protection. Circular 348 (Tech.). Fla. Coop. Ext. Serv., Inst. of Food and Agr. Sci., Univ. of Fla., Gainesville, FL.

Heinemann, P., C. Morrow, T. Stombaugh, B. Goulart, and J. Schlegel. 1992. Evaluation of an automated irrigation system for frost protection. Appl. Eng. Agr. 8:779-785.

Koc, A.B., P.H. Heinemann, R.M. Crassweller, and C.T. Morrow. 2000. Automated cycled sprinkler irrigation system for frost protection of apple buds. Appl. Eng. Agr. 16:231240.

Li, Q., J. Chen, R.H. Stamps, and L.R. Parsons. 2008. Variation in chilling sensitivity among eight Dieffenbachia cultivars. HortScience 43: $1742-1745$.

Mee, T.R. and J.F. Bartholic. 1979. Man-made fog, p. 334-352. In: Barfield, B.J. and J.F. Gerber (eds.). Modification of the aerial environment of plants. Amer. Soc. of Agr. Eng. Monogr. No. 2, St. Joseph, MI.

National Climate Data Center. 2008. Climatological Data Annual Summaries-Florida. U.S. Dept. of Commerce, Natl. Oceanic and Atmospheric Administration, Natl. Environmental Satellite, Data, and Info. Serv. 14 Aug. 2009 $<$ http://www7.ncdc.noaa.gov/IPS/cd/cd.html? _page $=0$ \&jsessionid $=$ A50481FDDB5BC9A82 BAC9B6604E51C59\&state $=$ FL\&_target $1=$ Next $>$.

Parsons, L.R., B.S. Combs, and D.P.H. Tucker. 1985. Citrus freeze protection with microsprinkler irrigation during an advective freeze. HortScience 20:1078-1080.

Parsons, L., T. Wheaton, N. Faryna, and J. Jackson. 1991a. Improved citrus freeze protection with elevated microsprinklers. Proc. Fla. State Hort. Soc. 104:144-147.

Parsons, L.R., T.A. Wheaton, N.D. Faryna, and J.L. Jackson. 1991b. Elevated microsprinklers improve protection of citrus trees in an advective freeze. HortScience 26:1149-1151.

Parsons, L.R., T.A. Wheaton, and J.D. Whitney. 1982. Undertree irrigation for cold protection with low-volume microsprinklers. HortScience 17:799-801.

St. Johns River Water Management District. 2004. Water conservation plan form for fern/nursery irrigation. St. Johns River Water Management District, Palatka, FL.

Stamps, R.H. 1989. Icing of shade fabric enhances cold protection of shadehouses during radiation freezes. HortScience 24:517.

Stamps, R.H. 1991. Cold protection of leatherleaf fern using crop covers and overhead irrigation in shadehouses. HortScience 26:862-865.

Stamps, R.H. 1994. Intermittent irrigation for cold protection conserves water in iced shadehouses during radiation freezes. Proc. Fla. State Hort. Soc. 107:204-207.

Stamps, R.H. and D.Z. Haman. 1991. Cold protection of leatherleaf fern in Lake, Putnam, and Volusia Counties, Florida. St. Johns River Water Management District Special Publication 91SP15.

Stamps, R.H. and D.D. Mathur. 1982. Reduced water application rates and cold protection of leatherleaf fern. Proc. Fla. State Hort. Soc. 95: 153-155.

Stamps, R.H. and D.W. McColley. 1996. Preliminary comparison of three full circle impact sprinklers for cold protection in shadehouses. Proc. Fla. State Hort. Soc. 109:14-16.

Stombaugh, T., P. Heinemann, C. Morrow, and B. Goulart. 1992. Automation of a pulsed irrigation system for frost protection of strawberries. Appl. Eng. Agr. 8:597-602.

USDA/NASS. 2010. Floriculture Crops 2009 Summary. U.S. Dept. Agr., Natl. Agr. Stat. Serv., Agr. Stat. Board, Sp Cr 6-1 (10), Washington, DC.

Yelenosky, G. 1997. An overview of Florida citrus freeze survival. Proc. Fla. State Hort. Soc. 109: 118-123. 